\title{
Contributors to Undergraduates' Perception of Skill Acquisition across Time
}

\author{
Andreia Costa ${ }^{1}$, Georges Steffgen ${ }^{1}$ \\ ${ }^{1}$ University of Luxembourg, Luxembourg \\ Correspondence: Andreia Costa, University of Luxembourg, Route de Diekirch, 7220-Walferdange, Luxembourg
}

Received: March 18, 2015 Accepted: April 9, $2015 \quad$ Online Published: June 25, 2015

doi:10.11114/jets.v3i5.727 URL: http://dx.doi.org/10.11114/jets.v3i5.727

\begin{abstract}
The present study examined the relation between the amount of years of study and the perception of skill acquisition through indicators of students' satisfaction with the course program. It was hypothesized that the more years students spend at the university, the higher their perception of skill acquisition and that factors related to the course program moderate this relationship. Participants were 314 undergraduate students in psychology who completed the Bachelor Evaluation Questionnaire, which assessed the perceived quality of the course program. Factor analysis revealed that the questionnaire assessed five different factors: Teachers and teaching, Course climate, Learning promotion, Course requirements, and Skill acquisition. A sub-sample of 117 students, who evaluated the course on their first and again on their fifth semester, was used to examine the change on perception of skill acquisition and the influence of course related factors on that change. It was found that students' perception of skill acquisition increased from first to fifth semester and that this increase was moderated by students' perception of learning promotion. Those with early low perception of learning promotion were at greater disadvantage of increasing perceived skill acquisition during their studies. Those with early high learning promotion but with early low perception of skill acquisition at the beginning, reached similar levels of perceived skill acquisition by the end of their studies as those with early high perception of skill acquisition. The implications of these findings for theory and practice in relation to academic achievement are discussed.
\end{abstract}

Keywords: skill, academic achievement, undergraduate, predictor, moderator

\section{Introduction}

Acquiring new skills is a recurrent challenge encountered by undergraduate students. Students are confronted with more skills to be acquired in a bigger range of areas and at a faster pace when entering the university. Specifically, undergraduate programs in psychology often require that students acquire a set of transferable skills, such as oral and writing communications, working in groups, problem solving, and information technology but also that they master theoretical concepts, learn how to conduct research and be prepared to do psychological intervention. How students perceive their skill acquisition is important as it has an impact on their future training as well as on strategic decisions in ongoing study programs. Based on that perception, students, on the one hand, will make choices concerning which are their strongest skills, and therefore how to take advantage of these. On the other hand, they will decide which skills need improvement. In the present study, the factors that influence psychology students' perception of skill acquisition will be analyzed and discussed.

The acquisition of skills is a predominant factor in everyday life. Anyone who wishes to acquire a skill can either try to learn by imitation, by trial-and-error, or can seek the help of an instructor or instruction manual (Dreyfus \& Dreyfus, 1980). Independently of the strategy used to acquire a skill, this process is time consuming and demands an effort from the person desiring to learn. In one of the earliest articles on the theory of skill acquisition, Anderson (1982, p.369) postulated that "it requires at least 100 hours of learning and practice to acquire any significant cognitive skill to a reasonable degree of proficiency." The exact amount needed to acquire a skill is hard to define and depends on many factors such as the task characteristics, personal engagement, and capacities. Skill acquisition can be defined as a form of prolonged learning where through many pairings of similar stimuli with particular responses, a person can begin to develop knowledge of how to respond in certain situations (Speelman \& Kirsner, 2005).

Three main theories of skill acquisition can be differentiated. The automaticity-based theories (Fitts \& Posner, 1967; 
Shiffrin \& Schneider, 1977; Anderson, 1982) postulate that the acquisition of skills proceeds in accordance with approximate segments of practice and that there are three stages in this process. The skill acquisition process begins with resource dependency, proceeds to an increase in speed performance and accuracy achieved through practice, and culminates in skilled performance or automaticity. The knowledge-based theories (Crossman, 1959; Gibson, 1963; Chase \& Simon, 1973; Ericsson \& Kintsch, 1995) assert that with extended experience, experts acquire a large number of more complex patterns and use these new patterns to store knowledge about which actions should be taken in similar situations. Skill acquisition is achieved through three principles: information is encoded with numerous and elaborate cues related to prior knowledge, experts develop a retrieval long-term memory structure, and the time required by encoding and retrieval operations decreases with practice (Gobet, 2000). Finally, the psychometric theories (Fleishman, 1972; Ackerman, 1988) suggest that ability-performance relations, but not skills such as chess mastery or physics problems, are sensitive to the consistency and complexity of the target task. Tasks with predominantly inconsistent stimulus-to-response mappings are expected to show little change in ability demands over practice, while other tasks that require consistent information-processing constraints are expected to show changes in ability demands as the learner develops the appropriate task skills (Ackerman \& Cianciolo, 2000).

Acquiring skills to the point of becoming an expert requires that a person's performance is superior to other people, that it produces concrete results and that the performance can be measured and replicated (Ericsson, Prietula, \& Cokely, 2007). Skill acquisition at a bachelor level in psychology can be measured through exams, oral presentations, and written reports. Although expertise can be nuanced by criteria of assessment and situational factors, students who have a superior level of expertise will have consistently better results compared to their peers.

Skill acquisition is intrinsically related to learning processes and how learning is promoted. In the context of formal learning, for teaching to be effective, it must have a learning function for the learner and ultimately promote learning processes within the learner (Tomlinson, 2008). Successful acquisition of skills requires the integration of both how teachers influence learning promotion in students and how this promotion is monitored (Tomlinson, 2008). Teachers themselves can be defined as promoters of learning (Malderez \& Wedell, 2007). However, for learning to occur and for skills to be acquired, teachers cannot do students' learning for them. Students must be active actors in their own learning promotion.

During undergraduate years, students must acquire a vast amount of skills that will prepare them to the job market or for further studies. The required skills must not only be related to the topic being studied but must also be skills that are readily transferable across a range of contexts and that can be easily adapted to changing job or study demands. The main transferable skills are the ability to cooperate, communicate, solve problems, use information technology, learn how to learn, and use the application of number (Bennett, Dunne, \& Carré, 1999; Murphy, 2001; Tariq \& Cochrane, 2003). The achievement of higher order cognitive skills such as conceptual, analytical, communication and problem solving skills represents a key aspect of the quality of learning and teaching outcomes. Therefore, this must be a relevant aspect to be considered during undergraduate studies. The development of relevant skills is also a major instrument for better working conditions. Skill enhancement improves productivity as well as income and reduces work drudgery and occupational risks (Liimatainen, 2002).

Factors such as the intellectual stimulation and challenges encountered in the classroom, students' interaction with other students and staff, the nature of the learning climate in the institutions, and personal development are known to contribute to students' positive outcomes (McInnis, Griffin, James, \& Coates, 2001) and have an impact on their acquisition of skills. Other factors such as the amount of years of study also influence the perception of acquired skills in students (McInnis et al., 2001). In accordance with the theories of skill acquisition the more time an individual dedicates to learn a skill (Anderson, 1982) and the more a person goes through the different stages of increasing skills (Dreyfus \& Dreyfus, 1980), the higher the amount of skill acquisition and, in turn, the perception of this increase.

Students' perceptions of skill acquisition are often assessed through course evaluations. Besides measuring students' perceptions of acquired skills, these evaluations often additionally take into account their satisfaction with materials and facilities offered to them, the quality of teachers and content being taught, as well as other factors related to the university or course program priorities. Similar evaluations are frequently used across courses in most universities and are carried out at least once a year either utilizing online or paper-and-pencil questionnaires.

Although there is empirical support for factors influencing skill acquisition in academic and non-academic context, a strong theoretical background of how different conditions influence students' perception of skill acquisition is still missing. Therefore, the research objective of the present study is twofold. First, we aim at assessing the psychometric properties of the Bachelor Evaluation Questionnaire, designed to assess several dimensions of students' perceptions of the quality of their course experience. Second, we seek to analyze the association between the years spent at the university and the perception of skill acquisition. Based on the evidence for the relationship between the amount of 
years of study and skill acquisition, it is hypothesized that students' perception of skill acquisition will increase with years spent at the university. Furthermore, based on the rationale that course characteristics are related to the acquisition of skill acquisition, a second hypothesis is tested. Factors such as students' perception and satisfaction with learning promotion, the course atmosphere, the perceived quality of teaching, and the required workload will moderate the relationship between the years spent at the university and the perception of skill acquisition.

\section{Method}

\subsection{Participant Characteristics}

To evaluate the psychometric properties of the questionnaire evaluations from 314 undergraduate students enrolled in the first semester of a 3-year long bachelor program in psychology at the University of Luxembourg were used. Of these students 253 were female (81\%), 55 were male (17\%), and $6(2 \%)$ did not report their gender. To analyze the change in perception of skill acquisition across time, a sub-sample of 117 undergraduate students, who evaluated the course on their first and again on their fifth semester, was used resulting in 234 evaluations. Of these students 96 were female $(82 \%)$ and 21 were male $(18 \%)$.

\subsection{Course Program}

The bachelor in psychology at the University of Luxembourg is trilingual and students must have good command of German, French, and English. The course program is offered since the academic year of 2005/06 and the studies extend over a period of three years (six semesters) conducting to a bachelor diploma (B.Sc.) in psychology and lead to the possibility of pursuing Master's degree studies.

The course program aims at providing a well-founded scientific background as well as knowledge in essential psychological theories that will prepare students to conduct research and to be prepared for the professional activity in psychology. The goals of the course program are for students to acquire skills in theory, methodology, intervention and advanced personal competences (Steffgen, Costa, \& Le Bihan, 2013).

\subsection{Measures}

Bachelor Evaluation Questionnaire: The Bachelor Evaluation Questionnaire (BEQ), a 16-item inventory, was administered as a measure of the perceived quality of the course program, and consists of five subscales. The BEQ assesses Skill acquisition, students' perceptions of the theoretical, transferable (practical) and research skills (e.g., "Through my current psychology studies, I was able to acquire practical knowledge"; 3 items; $\alpha=.60$ ), Learning promotion, students' satisfaction with the development of critical thinking and learning (e.g., "Through my current psychology studies, my willingness to question knowledge was encouraged"; 3 items; $\alpha=.73$ ), Course climate, students' satisfaction with the course and university atmosphere (e.g., "How satisfied are you with the course climate?"; 3 items; $\alpha=.68$ ), Teachers and teaching, students' satisfaction towards teachers and the quality of teaching (e.g., "How satisfied are you with the teaching presentation?"; 5 items; $\alpha=.75$ ), and Course requirements, students' satisfaction with the amount of workload (e.g., "How satisfied are you with the required workload?"; 2 items; $\alpha=.78$ ).

Table 1. Descriptive Statistics: Mean $(M)$, Standard Deviation $(S D)$, Inter-Item Correlation. Cronbach's Alpha $(\alpha)$, and Inter-Correlation for all Subscales $(n=314)$

\begin{tabular}{lcccccccc}
\hline & & & & & \multicolumn{5}{c}{ Correlations } \\
\cline { 5 - 9 } Scale & $M$ & $S D$ & $\begin{array}{c}\text { Inter-item } \\
\text { correlation }\end{array}$ & $\alpha$ & 1 & 2 & 3 & 4 \\
\hline 1. Course climate & 4.53 & 0.82 & .50 & .68 & - & & \\
2. Course requirements & 4.40 & 0.85 & .66 & .78 & $.36^{*}$ & - & \\
3. Learning promotion & 4.38 & 0.80 & .55 & .73 & $.29 *$ & $.40^{*}$ & - & \\
4. Teachers and teaching & 4.37 & 0.65 & .52 & .75 & $.27 *$ & $.29 *$ & $.41^{*}$ & - \\
5. Skill acquisition & 4.21 & 0.78 & .43 & .60 & $.22^{*}$ & $.25^{*}$ & $.41^{*}$ & $.35^{*}$ \\
\hline
\end{tabular}

$* p<.001$.

Table 1 shows the descriptive statistics for each of the assessed scales. Students answered to each item, indicating their level of satisfaction on a Likert scale ranging from $1=$ "not at all" to $6=$ "fully". The highest satisfaction was reported for Course climate $(M=4.53 ; S D=0.82)$, followed by Course requirements $(M=4.40 ; S D=0.85)$, Learning promotion $(M=4.38 ; S D=0.80)$, Teachers and teaching $(M=4.37 ; S D=.65)$, and Skill acquisition $(M=4.21 ; S D=$ $0.78)$. Items for each subscale are listed in the appendix.

\subsection{Procedure}

Most students of the three academic years completed the BEQ at the end of each winter term, in December, within the 
framework of one course. For the purpose of the present study, only evaluations from students enrolled in the first year (first semester) and in the last year (fifth semester) were considered. Since the academic year of 2007/08 until the academic year of 2014/15 the data were collected at seven time points. Students answered a paper-and-pencil German version of the BEQ. Answering the questionnaire took 10 minutes and participants received no extra credits for completing the questionnaire.

\section{Results}

A principal axis factor analysis (direct oblimin rotation with Kaiser Normalization) yielded a five factors solution (Table 2). An examination of the Kaiser-Meyer-Olkin measure of sampling adequacy was appropriate $(K M O=.82)$ and Bartlett's test of sphericity was significant $\left(\chi^{2}(120)=1485.71, p<.001\right)$. The diagonals of the anti-image correlation matrix were all $>.69$, supporting the inclusion of each item into the factor analysis. Finally, the communalities were all > .30, except for item 13 which was .27 (Table 2), further confirming that each item shared some common variance with other items. Given these overall indicators of sample adequacy, the analyses were conducted with all 16 items. The loadings were satisfactory, ranging from .301 to .846 in all items (Table 2). The initial eigenvalues showed that one factor, the scale Teachers and teaching, explained $29.98 \%$ of the total variance, and the remaining four factors explained each between $10.52 \%$ and $6.50 \%$ of the total variance.

Table 2. Exploratory factor analysis: Principal axis factor analysis. Direct oblimin rotation with Kaiser Normalization for the Bachelor Evaluation Questionnaire

\begin{tabular}{|c|c|c|c|c|c|c|c|}
\hline \multirow[t]{2}{*}{ Components } & \multirow[t]{2}{*}{ Items } & \multicolumn{5}{|c|}{ Loadings } & \multirow[t]{2}{*}{ Communalities } \\
\hline & & 1 & 2 & 3 & 4 & 5 & \\
\hline \multirow{5}{*}{ Teachers and teaching } & 10 & .799 & & & & & .63 \\
\hline & 9 & .670 & & & & & .57 \\
\hline & 11 & .626 & & & & & .37 \\
\hline & 13 & .468 & & & & & .27 \\
\hline & 12 & .357 & & & & & .35 \\
\hline \multirow[t]{3}{*}{ Course climate } & 1 & & .807 & & & & .66 \\
\hline & 3 & & .673 & & & & .47 \\
\hline & 2 & & .328 & & & & .37 \\
\hline \multirow{3}{*}{ Learning promotion } & 7 & & & -.807 & & & .65 \\
\hline & 6 & & & -.709 & & & .51 \\
\hline & 8 & & & -.343 & & & .40 \\
\hline \multirow[t]{2}{*}{ Course requirements } & 4 & & & & -.846 & & .71 \\
\hline & 5 & & & & -.769 & & .63 \\
\hline \multirow{3}{*}{ Skill acquisition } & 15 & & & & & .780 & .62 \\
\hline & 16 & & & & & .544 & .34 \\
\hline & 14 & & & & & .301 & .37 \\
\hline Eigenvalues & & 4.796 & 1.683 & 1.470 & 1.235 & 1.039 & \\
\hline $\begin{array}{l}\text { Percentage of explained } \\
\text { variance }\end{array}$ & & 29.978 & 10.517 & 9.187 & 7.717 & 6.495 & \\
\hline
\end{tabular}

Note. Only the loadings superior or equal to .30 are presented.

Pearson product-moment correlations revealed that all subscales were significantly correlated with each other (Table 1). However, there was no multicollinearity in the data. All VIF values were $<10$ and the tolerance statistics were all $>0.20$. Internal consistency (Cronbach's alpha) for each of the scales was moderate and ranged between .60 and .78 (Table 1). No substantial increases in alpha for any of the scales could have been achieved by eliminating items.

A paired-samples $t$-test between students' evaluations in the first and fifth semesters was conducted to verify the first hypothesis that the perception of skill acquisition increases with the years spent at the university. It was found that on average, students' scores of their perception of skill acquisition increases from the first semester $(M=4.14, S D=0.82)$ to the fifth semester $(M=4.71, S D=0.72)$. This difference, 0.57 , BCa 95\% CI [-0.72, -0.40], was significant $t(116)=$ $-6.95, p<.001$, and represented a medium-sized effect, $d=0.70$. 
Table 3. Correlations between measures.

\begin{tabular}{|c|c|c|c|c|c|c|}
\hline & 1 & 2 & 3 & 4 & 5 & 6 \\
\hline 1. Gender & - & & & & & \\
\hline $\begin{array}{l}\text { 2. Teachers and teaching } \\
\text { (semester } 1)\end{array}$ & .10 & - & & & & \\
\hline $\begin{array}{l}\text { 3. Course climate (semester } \\
\text { 1) }\end{array}$ & -.10 & $.30 * *$ & - & & & \\
\hline $\begin{array}{l}\text { 4. Learning promotion } \\
\text { (semester 1) }\end{array}$ & .01 & $.37 * * *$ & $.35 * * *$ & - & & \\
\hline $\begin{array}{l}\text { 5. Course requirements } \\
\text { (semester 1) }\end{array}$ & .11 & $.37 * * *$ & $.34 * * *$ & $.50 * * *$ & - & \\
\hline $\begin{array}{l}\text { 6. Skill acquisition } \\
\text { (semester } 1)\end{array}$ & -.07 & $.36 * *$ & $.31 * *$ & $.44 * * *$ & $.33 * * *$ & - \\
\hline $\begin{array}{l}\text { 7. Skill acquisition } \\
\text { (semester 5) }\end{array}$ & -.03 & $.24 * *$ & .15 & $.28 * *$ & .14 & $.36^{* * * *}$ \\
\hline
\end{tabular}

To test the hypothesis that the increase in the perception of skill acquisition from first semester to the fifth semester is moderated by students' satisfaction with other course characteristics, bivariate analyses were conducted followed by multivariate analyses. Pearson product-moment correlations revealed that skill acquisition in fifth semester $\left(\right.$ Skill $\left.5^{\text {th }}\right)$ was related, as expected, to skill acquisition in first semester (Skill $1^{\text {st }}$ ), but also to teachers and teaching $\left(\right.$ Teach $\left.1^{\text {st }}\right)$, and to learning promotion in first semester (Promote $1^{\text {st }}$; Table 3 ).

Table 4. Two-Step Hierarchical Multiple Regression Analysis for variables predicting perception of skill acquisition in fifth semester $(n=117)$. Predictors: $z$-standardized skill acquisition in first semester (Skill $1^{\text {st }}$ ), learning promotion in first semester (Promote $1^{\text {st }}$ ), and the cross product of both.

\begin{tabular}{lcccc}
\hline & $b$ & SE $B$ & $\beta$ & $p$ \\
\hline Step 1 & & & & \\
$\quad$ Constant & 4.71 & 0.06 & & $p<.01$ \\
$\quad$ Skill 1 $1^{\text {st }}$ & 0.26 & 0.06 & .36 & $p<.01$ \\
Step 2 & & & & \\
$\quad$ Constant & 4.76 & 0.07 & & $p<.01$ \\
$\quad$ Skill $1^{\text {st }}$ & 0.22 & 0.07 & .31 & $p<.01$ \\
$\quad$ Promote $1^{\text {st }}$ & 0.11 & 0.07 & .15 & $p=.113$ \\
$\quad$ Skill $1^{\text {st }} \times$ Promote $1^{\text {st }}$ & -0.12 & 0.05 & -.20 & $p<.05$ \\
\hline
\end{tabular}

Note. $R^{2}=.36$ for Step $1 ; \Delta R^{2}=.06$ for step $2(p \mathrm{~s}<.05)$.

Further preliminary moderation analysis were carried out with the correlated predictors and Teach $1^{\text {st }}$ was found to not be a predictor of Skill $5^{\text {th }}$. Therefore, to test the predicted moderation effects of Skill $1^{\text {st }}$ and Promote $1^{\text {st }}$, a two-step hierarchical multiple regression analysis was conducted (Table 4). Regressing Skill $5^{\text {th }}$ on $z$-standardized Skill $1^{\text {st }}$, Promote $1^{\text {st }}$ and the cross product of both predictors incrementally accounted for a significant amount of variance of the dependent variable. On multivariate level Skill $1^{\text {st }}$ but not Promote $1^{\text {st }}$ was associated with higher perception of Skill $5^{\text {th }}$. Furthermore, the predicted interaction effect was confirmed, as the interaction of Skill $1^{\text {st }}$ and Promote $1^{\text {st }}$ incrementally predicted Skill $5^{\text {th }}$ above and beyond Skill $1^{\text {st }}$ main effect on the dependent variable (Table 4). For students exhibiting high Promote $1^{\text {st }}(+1 S D)$, no link between Skill $1^{\text {st }}$ and Skill $5^{\text {th }}$ was found (Figure 1). In contrast, students with low Promote $1^{\text {st }}(-1 S D)$ exhibited a positive link between Skill $1^{\text {st }}$ and Skill $5^{\text {th }}$. Simple slope analyses confirmed this interpretation: Skill $1^{\text {st }}$ had no effect for students with high Promote $1^{\text {st }}, b=0.11, S E=0.08, p=.195$ but a significant positive effect for students with low Promote $1^{\text {st }}, b=0.34, S E=0.09, p<.01$.

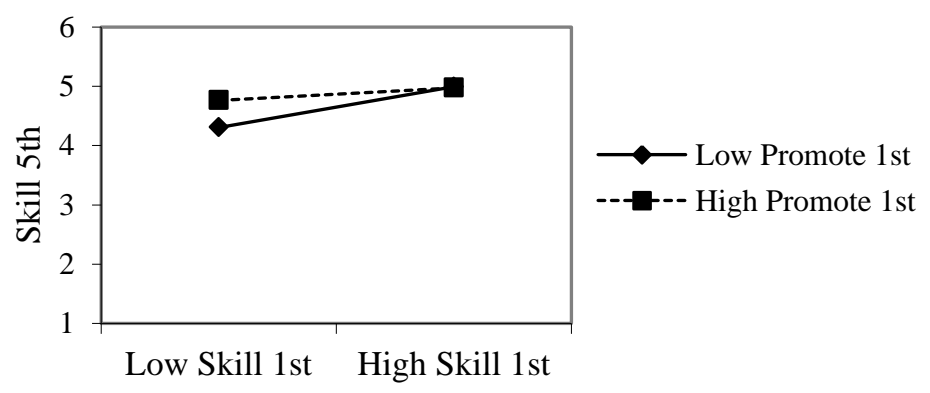

Figure 1. Skill acquisition in fifth semester $\left(\right.$ Skill $\left.5^{\text {th }}\right)$ as function of skill acquisition in first semester $\left(\right.$ Skill $\left.1^{\text {st }} ; \pm 1 S D\right)$ and learning promotion in first semester (Promote $1^{\text {st }} ; \pm 1 S D$ ). 


\section{Discussion}

The first aim of the present study was to assess the psychometric properties of the BEQ, a questionnaire evaluating students' perceptions of the quality of a bachelor in psychology study program. The questionnaire is composed of 16 items and covers five different factors related to students' perceptions of the quality of their course experience: teachers and teaching, course climate, learning promotion, course requirements, and skill acquisition. These five subscales yielded moderate internal consistencies and provided indicators of students' satisfaction with different important factors of undergraduates' experiences.

The second aim of the study was to analyze the relation between the amount of years spent at the university and the perception of skill acquisition. More specifically, it aimed at testing if, as the literature suggests, perception of skill acquisition increases as a function of years spent at the university and whether this relation is moderated by other factors that have been identified in the literature as important contributors for the perception of skill acquisition. Although there is empirical support for factors influencing skill acquisition in academic and non-academic contexts, a strong theoretical background of how different conditions influence students' perception of skill acquisition is still missing.

As a first step, the perception of students' skill acquisition at the beginning of the studies (first semester) was compared to the perception of skill acquisition at the end of the studies (fifth semester). It was found that a significant increase in perceived skill acquisition was observed from first to fifth semesters. This result is in accordance with studies indicating that skill acquisition improves with years spent at the university (McInnis et al., 2001). However, in previous studies (see McInnis et al., 2001) the assessment of perceived skill acquisition across years was achieved through an inter-subjects design. Students enrolled at different years were simultaneously assessed and compared. In the present study, a longitudinal comparison of skill acquisition was conducted. Students' perception of skill acquisition both at the beginning and at the end of their studies was compared. This result therefore, supports and strengthens previous findings that the perception of skill acquisition increases with years spent at the university.

As a second step to understand skill acquisition, particularly to understand which factors influence the increase from first to fifth semesters, bivariate correlations and regression analysis were conducted. Factors from first semester that could, concurrently with skill acquisition in first semester, explain the perception of skill acquisition in fifth semester were examined. From the four remaining factors measured by the BEQ only Teachers and teaching and Learning promotion in the first semester were significantly correlated to Skill acquisition in the fifth semester.

Teachers and teaching in first semester revealed to be positively correlated to Skill acquisition in fifth semester. On the one hand, when students perceive teaching as involving it can have a positive impact on their perception of skill acquisition. On the other hand, having the impression that skills are being acquired might lead to the conclusion that teaching is being effective. The results of this study are in accordance with previous studies in which teachers' quality and teachers' experience had a positive relationship with students' achievement and perceptions of skill acquisition (Greenwald, Hedges, \& Laine, 1996; Hanushek, 1996; Lizzio, Wilson, \& Simons, 2002; Zhang \& Aasheim, 2011). Teachers' inadequate behaviors and methods are also among the best predictors of academic failure (Aysan et al., 1996).

Learning promotion in first semester also revealed to be positively correlated to Skill acquisition in fifth semester. The way students see their learning promotion early on their studies can be related to how they later perceive their skills acquisition. Learning promotion is closely related to students' willingness and motivation to improve their learning.

Finally, preliminary moderation analysis revealed that Learning promotion, but not Teachers and teaching in first semester had a significant effect on Skill acquisition in fifth semester. Specifically, students with low perception of learning promotion at the beginning of their studies benefited the most from a high perception of skill acquisition at the beginning in order to have a higher perception of skill acquisition at the end of the studies. Whereas students with already high perception of learning promotion did not benefit from having a higher perception of skill acquisition at the beginning. Therefore, those students with the lowest perception of learning promotion at the beginning of their studies were at a greater risk of not achieving higher perception of skill acquisition at the end of their studies. Among those students, the ones with low perception of skill acquisition at the beginning did not report an increase in skill acquisition from the first to the fifth semesters. These results are in line with the motivation and self-efficacy theories (Bandura, 1977). Individuals with high-levels of self-efficacy are more able to cope with new situations and perform at higher levels (Noe, 1986). Students who are motivated and think of themselves as capable approach difficulties and challenges in a more efficient way. This approach, allows these students, even those with low perception of skill acquisition, to attain similar levels of skill acquisition in the end as those with a priori higher perception of skill acquisition.

Other factors such as Course requirements and Course climate, which have been identified in the literature as important for the perception of skill acquisition, have not been found to play a determinant role. Course requirements, in our study did not have an influence on skill acquisition at the end of the studies. This result contradicts previous studies that have 
shown that appropriate workload is a relevant predictor of both academic satisfaction and perception of the acquisition of transferable and theoretical skills (Entwistle \& Tait, 1990; Lizzio et al., 2002). Courses with less workload enable students to use learning processes that facilitate the synthesis, integration, and application of knowledge (Lizzio et al., 2002). Regarding the impact of course climate on skill acquisition, previous research is inconclusive regarding the importance of this factor. On the one hand, studies indicate that the social climate, academic and social integration, and campus climate are important factors for academic achievement (Wince \& Borden, 1995; Volkwein, Valle, Parmley, Blose, \& Zhou, 2000). On the other hand, studies assessing students' rankings of important factors for academic achievement show that these factors are ranked low (Zhang \& Aasheim, 2011).

\section{Recommendations}

Some factors are recognized to be important to academic achievement such as learning promotion, motivation, the learning climate in the institutions, the quality of teachers, the relevance and structure of the course content, and the interaction with other students and staff. In the present study, the most important factors for skill acquisition were Learning promotion and Teachers and teaching. Of these two factors learning promotion, which revealed to play a determinant role on how students increase skill acquisition with time, is highly related to motivational processes and to students' willingness to learn. Therefore, this aspect is mostly intrinsic to the individual and can only be partly controlled by universities or teachers. Universities can contribute to the improvement of learning promotion by creating stimulating environments with interesting topics and innovative approaches to learning. Furthermore, providing individuals with experiences of self-efficacy will influence their perception of learning promotion and increase their motivation (Bandura, 1993). Allowing students to experience success at university level will give them important motivation to face challenges effectively throughout their studies and acquire skills. The other factor, quality of teachers and teaching, is directly related to the quality of teachers since they are the ones who define their teaching style and can therefore be more easily controlled by universities. In order to improve academic achievement in students it is important for universities to offer high quality teaching. It is most fundamental that universities focus on improving students' satisfaction with the content being taught and the quality of their teachers to promote a greater perception of skill acquisition. For this, it is important that universities find effective measures of teaching quality and reward high quality teaching. Finally, it is important that these two factors, and more particularly the perception of learning promotion, be encouraged at an early stage.

\section{Limitations}

It has to be noted that the present study assessed students' perception of skill acquisition and not actual skill acquisition. Even though the perception of the learning environment can directly influence the learning outcomes (Biggs, 1989), the gap between these two characteristics might be of importance to the explained variance. Relevant individual factors such as personal engagement and motivation are only partly considered in the present study. A study assessing these factors could further open access to fundamental contributors to skills acquisition (Kanfer, 1987; Crebert, Bates, Bell, Patrick, \& Cragnolini, 2004).

The evaluations were conducted at the end of each winter term, which implicates that no evaluation was conducted at the end of the studies. It would have been important to assess students' satisfaction once they had finished their studies and could have a general overview of their satisfaction.

\section{Conclusions}

Actually acquired theoretical and transferable skills and the subjective perception of it are important factors of academic achievement and employability. The present study provides valuable findings on the importance of students' perception of learning promotion for the improvement of skill acquisition across the years at university. Of particular interest was the finding that in the one hand students with low perception of learning promotion at the beginning of their studies are at a greater disadvantage of perceiving skills acquisition during their studies. On the other hand, those with high perception of learning promotion, even with low perception of skill acquisition at the beginning, will attain similar levels of perceived skill acquisition by the end of their studies as those who had already a high level at the beginning. An important implication of this study is that students' perceptions of their success in undergraduate studies are linked to factors that can be, to some extent, controlled by the university. Improving the effects of a course program might be achieved by enhancing teachers' engagement and students' learning promotion through the experience of self-efficacy.

\section{References}

Ackerman, P. L. (1988). Determinants of individual differences during skill acquisition: Cognitive abilities and information processing. Journal of Experimental Psychology: General, 117(3), 288-318. http://dx.doi.org/10.1037/0096-3445.117.3.288

Ackerman, P. L., \& Cianciolo, A. T. (2000). Cognitive, perceptual-speed, and psychomotor determinants of individual 
differences during skill acquisition. Journal of Experimental Psychology, 6(4), 259-290. http://dx.doi.org/10.1037//1076-898X.6.4.259

Anderson, J. R. (1982). Acquisition of cognitive skill. Psychological Review, 89(4), 369-406. http://dx.doi.org/10.1037/0033-295X.89.4.369

Aysan, F., Tanrı̈ğğen, G., \& Tanrı̈ğğen, A. (1996). Perceived causes of academic failure among the students at the faculty of education at Buca. U. S. Department of Education. (ERIC Document Reproduction Service No. ED406326). http://files.eric.ed.gov/fulltext/ED406326.pdf

Bandura, A. (1977). Social learning theory. Englewood Cliffs, NJ: Prentice-Hall.

Bandura, A. (1993). Perceiving self-efficacy in cognitive development and functioning. Educational Psychologist, 28(2), 117-148. http://dx.doi.org/10.1207/s15326985ep2802_3

Bennett, N., Dunne, E., \& Carré, C. (1999). Patterns of core and generic skill provision in higher education. Higher Education, 37(1), 71-93. http://dx.doi.org/10.1023/A:1003451727126

Biggs, J. B. (1989). Approaches to the enhancement of tertiary teaching. Higher Education Research \& Development, 8(1), 7-25. http://dx.doi.org/10.1080/0729436890080102

Chase, W. G., \& Simon, H. A. (1973). Perception in chess. Cognitive Psychology, 4, 55-81. http://dx.doi.org/10.1016/0010-0285(73)90004-2

Crebert, G., Bates, M., Bell, B., Patrick C.-J., \& Cragnolini, V. (2004). Developing generic skills at university, during work placement and in employment: graduates' perceptions. Higher Education Research \& Development, 23(2), 147-165. http://dx.doi.org/10.1080/0729436042000206636

Crossman, E. R. F. W. (1959). A theory of the acquisition of speed-skill. Ergonomics, 2(2), 153-166. http://dx.doi.org/10.1080/00140135908930419

Dreyfus, S. E., \& Dreyfus, H. L. (1980). A five-stage model of the mental activities involved in directed skill acquisition. California University Berkeley Operations Research Center. http://www.dtic.mil/dtic/index.html

Entwistle, N., \& Tait, H. (1990). Approaches to learning, evaluations of teaching, and preferences for contrasting academic environments. Higher Education, 19(2), 169-194. http://dx.doi.org/10.1007/BF00137106

Ericsson, K. A., \& Kintsch, W. (1995). Long-term working memory. Psychological Review, 102(2), 211-245. http://dx.doi.org/10.1037/0033-295X.102.2.211

Ericsson, K. A., Prietula, M. J., \& Cokely, E. T. (2007). The making of an expert. Harvard Business Review, July-August, 115-121.

Fitts, P. M., \& Posner, M. I. (1967). Human performance. Belmont, CA: Brooks/Cole.

Fleishman, E. A. (1972). On the relation between abilities, learning, and human performance. American Psychologist, 27(11), 1017-1032. http://dx.doi.org/10.1037/h0033881Gibson, E. J. (1963). Perceptual learning. Annual Review of Psychology, 14, 29-56. http://dx.doi.org/10.1146/annurev.ps.14.020163.000333

Gobet, F. (2000). Some shortcomings of long-term working memory. British Journal of Psychology, 91(4), 551-570. http://dx.doi.org/10.1348/000712600161989

Greenwald, R., Hedges, L. V., \& Laine, R. D. (1996). The effect of school resources on student achievement. Review of Educational Research, 66(3), 361-396. http://dx.doi.org/10.3102/00346543066003361

Hanushek, E. A. (1996). A more complete picture of school resource policies. Review of Educational Research, 66(3), 397-409. http://dx.doi.org/10.3102/00346543066003397

Kanfer, R. (1987). Task-specific motivation: An integrative approach to issues of measurement, mechanisms, processes, and determinants. Journal of Social and Clinical Psychology, 5, 237-264. http://dx.doi.org/10.1521/jscp.1987.5.2.237

Liimatainen, M. R. (2002). Training and Skills Acquisition in the Informal Sector: A Literature Review. ILO InFocus Programme on Skills, Knowledge and Employability, Informal Economy Series, 9.

Lizzio, A., Wilson, K., \& Simons, R. (2002). University students' perceptions of the learning environment and academic outcomes: implications for theory and practice. Studies in Higher Education, 27(1), 27-52. http://dx.doi.org/10.1080/03075070120099359

Malderez, A., \& Wedell, M. (2007). Teaching teachers: Processes and practices. London: Continuum International Publishing Group. 
McInnis, C., Griffin, P., James, R., \& Coates, H., (2001). Development of the course experience questionnaire (CEQ). Report of Centre for the Study of Higher Education and Assessment Research Centre. http://www.cshe.unimelb.edu.au/research/policy_dev/docs/ceq.pdf

Murphy, R. (2001). A briefing on key skills in higher education. Assessment series 5, York, UK: LTSN.

Noe, R. A. (1986). Trainees' attributes and attitudes: Neglected influences on training effectiveness. Academy of Management Review, 11(4), 736-749. http://dx.doi.org/10.5465/AMR.1986.4283922

Shiffrin, R. M., \& Schneider, W. (1977). Controlled and automatic human information processing: II. Perceptual learning, automatic attending, and a general theory. Psychological Review, 84(2), 127-190. http://dx.doi.org/10.1037/0033-295X.84.2.127

Speelman, C. P., \& Kirsner, K. (2005). Skill acquisition: History, questions, and theories. C. P. Speelman, \& K. Kirsner (Eds.), Beyond the Learning Curve (pp. 26-64). USA: Oxford University Press. http://dx.doi.org/10.1093/acprof:oso/9780198570417.003.0002

Tariq, V. N., \& Cochrane, A. C. (2003). Reflections on key skills: Implementing change in a traditional university. Journal of Education Policy, 18(5), 481-498. http://dx.doi.org/10.1080/0268093032000124857

Tomlinson, P. (2008). Psychological theory and pedagogical effectiveness: The learning promotion potential framework. British Journal of Educational Psychology, 78(4), 507-526. http://dx.doi.org/10.1348/000709908X318672

Volkwein, J. F., Valle, S., Parmley, K., Blose, G., \& Zhou, Y. (2000). A multi-campus study of academic performance and cognitive growth among native freshman, two-year transfers, and four-year transfers. Paper presented at the Annual Forum for Institutional Research. (ERIC Document Reproduction Service No. ED445652). http://files.eric.ed.gov/fulltext/ED445652.pdf

Wince, M. H., \& Borden, V. (1995). When does student satisfaction matter? Paper presented at the Annual Forum for Institutional Research. (ERIC Document Reproduction Service No. ED386990). http://files.eric.ed.gov/fulltext/ED386990.pdf

Zhang, A., \& Aasheim, C. L. (2011). Academic success factors: an IT student perspective. Journal of Information and Technology Education, 10, 309-331.

\section{Appendix}

Table A1. Translation of the Items of Each Scale of the Study

\begin{tabular}{|c|c|}
\hline Scale & Items \\
\hline \multirow[t]{3}{*}{ Course climate } & 1. How satisfied are you with the course climate? \\
\hline & 2. How satisfied are you with the working atmosphere? \\
\hline & 3. A lot of contact can be made with other students. \\
\hline \multirow[t]{2}{*}{ Course requirements } & 4. How satisfied are you with the course requirements? \\
\hline & 5. How satisfied are you with the required workload? \\
\hline \multirow[t]{3}{*}{ Learning promotion } & 6. Through my current psychology studies, my willingness to question knowledge was encouraged. \\
\hline & 7. Through my current psychology studies, my willingness to actively research was encouraged. \\
\hline & 8. Through my current psychology studies, I was able to continually improve my learning. \\
\hline \multirow{5}{*}{$\begin{array}{l}\text { Teachers } \\
\text { teaching }\end{array}$} & 9. Teachers can create material that arise interest and motivation. \\
\hline & 10. The curriculum is presented in a comprehensible and clear manner. \\
\hline & 11. How satisfied are you with the teaching presentation? \\
\hline & 12. How satisfied are you with teachers / lecturers? \\
\hline & 13. How satisfied are you with the content design? \\
\hline \multirow[t]{3}{*}{ Skill acquisition } & 14. Through my current psychology studies, I was able to acquire theoretical knowledge. \\
\hline & 15. Through my current psychology studies, I was able to acquire practical knowledge. \\
\hline & 16. Through my current psychology studies, I was able to acquire research skills. \\
\hline
\end{tabular}

\section{(cc) BY}

This work is licensed under a Creative Commons Attribution 3.0 License. 